\title{
The Effects of Administration of Exogenous Albumin Early after Non-cardiac Surgery on Postoperative AKI in Patients with Preoperative Hypoalbuminemia: A Prospective Propensity-score Matching Analysis
}

\author{
Miao Yan \\ Peking University First Hospital \\ Wei-Jie Zhou \\ Peking University First Hospital \\ Min Xie \\ Peking University First Hospital \\ Sai-Nan Zhu \\ Peking University First Hospital \\ Nan Li ( $\square$ iculinan@163.com ) \\ Peking University First Hospital \\ Shuang-Ling Li \\ Peking University First Hospital
}

\section{Research Article}

Keywords: Hypoalbuminemia, Acute kidney injury, Exogenous albumin

Posted Date: December 8th, 2021

DOI: https://doi.org/10.21203/rs.3.rs-1131516/v1

License: (c) (i) This work is licensed under a Creative Commons Attribution 4.0 International License. Read Full License 


\section{Abstract}

Background

Evidence have shown that preoperative hypoalbuminemia is independently associated with acute kidney injury (AKI) after non-cardiac surgery. However, little study has investigated the effects of administration of exogenous albumin early after non-cardiac surgery on postoperative AKI in patients with preoperative hypoalbuminemia.

Methods

This study was a secondary analysis of the database of a previously conducted prospective cohort study. Data of 661 adult patients who underwent non-cardiac surgery and were admitted to Surgical Intensive Care Unit (SICU) after surgery from May 1, 2019 to November 30, 2020 were collected. 267 patients with preoperative hypoalbuminemia were screened, and divided into two groups according to whether they were administrated with exogenous albumin on the day of SICU admission. The demographic and perioperative data of the two groups were propensity-matched.

Results

After propensity score matching, 64 pairs of patients were included in the final analysis. The patients of albumin group showed relatively higher serum albumin level on postoperative day 1 than that in patients of control group (31.3 \pm 3.4 vs. $29.7 \pm 3.8, P=0.008$ ), however, no difference was observed in postoperative AKI incidence in patients of the two groups $(59.4 \%$ vs. $62.5 \%, P=0.717)$. Furthermore, there was no difference in other prognostic factors, such as the use of mechanical ventilation, occurrence of other postoperative complications, in-hospital mortality, length of SICU stay and postoperative hospital stay.

Conclusions

For patients with preoperative hypoalbuminemia following non-cardiac surgery, administration of exogenous albumin early after surgery had no beneficial effect on the incidence of postoperative AKI and other clinical outcomes.

\section{Introduction}

Acute kidney injury (AKI) is a common complication after surgery among different patient populations, and postoperative AKI is associated with poor outcomes[1]. In the absence of proven effective treatments for AKI, early recognition of modifiable risk factors and the development of renal protective strategies would be beneficial.

Perioperative hypoalbuminemia has proved to be a risk factor for increased incidence of postoperative AKI[2-7]. Renal protective properties of albumin have been shown in a mount of clinical and basic studies[8-11]. Serum albumin may play a protection role in the maintenance of effective circulating volume and renal perfusion, preservation of proximal tubular integrity and function, binding of endogenous toxins and nephrotoxic drugs, scavenging and limiting the production of reactive oxygen species, and delivery of protective lysophosphatidic acid. In addition, albumin can improve microcirculatory blood flow and reduce the inflammatory response.

In our previous study, a preoperative serum albumin level of less than $37.5 \mathrm{~g} / \mathrm{L}$ was found to be independently associated with postoperative AKI in patients undergoing non-cardiac surgery[2]. We suppose that correction of hypoalbuminemia may be a reasonable preventive strategy for postoperative AKI. Although administration of exogenous albumin for correcting hypoalbuminemia has been widely used in various clinical settings, there are limited data on whether perioperative albumin intravenous infusion affects the occurrence of postoperative AKI, and 
its usefulness is still a matter of debate[12]. This study was conducted to prospectively evaluate the effect of administration of exogenous albumin early after surgery on postoperative AKI occurrence in patients with preoperative hypoalbuminemia following non-cardiac surgery.

\section{Methods}

\section{Ethics and consent}

This study was a secondary analysis of the database of a previously conducted prospective cohort study investigating the perioperative predictors of AKI following non-cardiac surgery. Ethical approval (2019-075) was provided by the Clinical Research Ethics Committee of Peking University First Hospital. The privacy rights of participants were observed. The original study was conducted in the Surgical Intensive Care Units (SICU) of Peking University First Hospital from May 1, 2019 to November 30, 2020. Written informed consents were obtained from patients, their next of kin or their legal representatives.

\section{Patients}

The inclusion criteria included (1) adult patients (age $\geq 18$ years), (2) undergoing non-cardiac surgery, and (3) admitted to the SICU immediately after surgery. Patients with any of the following criteria were excluded: (1) preoperative chronic kidney disease stage 5 or requiring long-term dialysis; (2) surgery involving kidney, such as nephrectomy, partial nephrectomy, nephroureterectomy, or kidney transplantation; (3) AKI events before admission to SICU; (4) without Foley catheter placement; and (5) written informed consent not obtained. Our medical center is a teaching hospital affiliated with a university, which provides tertiary care and has about 1600 beds.

\section{Data collection}

Specially trained researchers were responsible for patient recruitment and data collection. The data of patients were collected from the electronic medical records system of our hospital. Preoperative information included demographic characteristics (age, gender), body mass index (BMI), medical history, nephrotoxin exposure, American Society of Anesthesiology (ASA) Classification of Physical Status, as well as preoperative clinical laboratory data. Intraoperative data included type and duration of surgery, surgical approach, anesthesia method, duration of anesthesia, estimated blood loss, occurrence of hypotension and duration, and use of vasoactive drugs. Postoperative data included nonrenal Sequential Organ Function Assessment (SOFA) score within 24h of SICU admission.

\section{Definition and outcomes}

The cutoff value of preoperative hypoalbuminemia was $37.5 \mathrm{~g} / \mathrm{L}$, which referred to our previous research reporting that preoperative serum albumin level less than $37.5 \mathrm{~g} / \mathrm{L}$ was an independent risk factor for AKI after non-cardiac surgery[2].

The timing of early administration of exogenous albumin was defined as being less than 12 hours after surgery. In our department, albumin is generally administrated either in patients who require a large amount of fluid resuscitation, or in patients who need to maintain a high colloidal osmotic pressure, such as patients with head injury and intracranial hypertension. Whether administration and further the amount of exogenous albumin after surgery in other patients were determined by doctors according to the clinical situation.

Postoperative follow-up was performed. The primary end point was postoperative AKI development. Postoperative $\mathrm{AKI}$ and its severity were defined according to Kidney Disease Improving Global Outcomes (KDIGO) criteria using the 
maximal change in serum creatinine compared with the preoperative baseline values and urine output during the first 7 postoperative days[13].

The secondary end points were the amount of early albumin infusion, the level of serum albumin on postoperative day 1, positive fluid balance on the day of SICU admission, postoperative use and duration of mechanical ventilation $(\mathrm{MV})$, length of stay in SICU and hospital after surgery, occurrence of postoperative complications other than AKI, and in-hospital mortality. Other main postoperative complications were pulmonary infection, pleural effusion, pulmonary atelectasis, respiratory failure, surgical bleeding, new-onset arrhythmia, acute myocardial infarction, hemodynamic insufficiency, stroke, ileus, anastomotic leakage, intra-abdominal abscess, acute liver injury, wound infection, wound dehiscence, urinary tract infection, sepsis, disseminated intravascular coagulation, digestive tract bleeding, and venous thromboembolism (Table S1).

\section{Statistical analysis}

The Kolmogorov-Smirnov method was used to test the normality of continuous variables. Normally distributed data were presented as mean \pm standard deviation (SD), and abnormally distributed data were presented as median (minimum-maximum). Categorical variables were presented as number (percentage). Analyses of the frequencies of categorical variables were performed using chi-squared test or Fisher's exact test. Differences in quantitative variables between two independent groups were tested with t-test or Mann-Whitney U test.

Several underlying susceptibilities, procedures, or exposures have been identified as risk factors of postoperative AKI occurrence[3,14].Variables being considered clinically relevant were used for propensity score matching and selected a priori. These variables included age, gender, BMI, preoperative comorbidities, preoperative and postoperative albumin, ASA classification, type and duration of surgery, type and duration of anesthesia, intraoperative hemodynamic instability and postoperative non-renal SOFA. The propensity score matching was conducted using multivariate logistic regression. Patients were matched in a 1:1 ratio based on their scores using the nearest-neighbor matching with the tolerance being 0.1. Between-group differences of baseline and perioperative variables for propensity score matching were compared using the absolute standardized differences (ASDs)[15], which were calculated as (mean1-mean2)/SD1. An ASD $\geq 0.250$ (ie, $1.96 \times \sqrt{(\mathrm{n} 1+\mathrm{n} 2) /(\mathrm{n} 1 \times \mathrm{n} 2)})$ was considered imbalanced between the two groups.

Data analyses was performed with SPSS 26.0. Two-tailed $P$ values lower than 0.05 were considered statistically significant.

\section{Results}

\section{Participants}

During the enrollment period, a total of 661 patients who underwent non-cardiac surgery and were admitted to SICU met the inclusion/exclusion criteria. Of the 247 patients with preoperative hypoalbuminemia, 130 received administration of exogenous albumin early after surgery (albumin group), and 117 did not receive postoperative early albumin infusion (control group). Propensity score matching was performed to match the baseline and perioperative variables. Ultimately, 64 pairs of patients were included in the final statistical analysis. Figure 1 showed the flow diagram of the study.

\section{Baseline and perioperative data}


In this study, the baseline and perioperative data of the 247 patients with preoperative hypoalbuminemia were analyzed. Compared with the patients of control group, those of the albumin group had more history of coronary heart disease, more ACEI/ARB medication history, lower preoperative and postoperative albumin; they underwent more emergency surgery, abdominopelvic surgery and general anesthesia; they had longer duration of surgery and anesthesia; they showed more intraoperative hypotension and received more vasoactive drugs; they had higher nonrenal SOFA within $24 \mathrm{~h}$ of SICU admission. After propensity score matching, the above variables of the two groups were well balanced (Tables 1-3).

\section{Primary and secondary end points}

The patients of albumin group were administrated with 20 (10-150) gram exogenous albumin early after surgery, and serum albumin on postoperative day 1 in patients of albumin group was higher than that in patients of control group [31.3 \pm 3.4 vs. $29.7 \pm 3.8, P=0.008$, which indicated that administration of albumin early after surgery did improve the albumin level on postoperative day 1 . However, there was no difference in postoperative AKI incidence in patients of the two groups ( $59.4 \%$ vs. $62.5 \%, P=0.717$ ). Furthermore, higher positive fluid balance on the day of SICU admission was observed in albumin group, but not statistically significant [36.5 (4.0-337.0) vs. 32.0 (4.0-128.0), $P=0.064]$ (Table 4).

Regarding secondary end points, no improvement was found in the patients of albumin group in the use and duration of MV, occurrence of other postoperative complications (Table S1), in-hospital mortality, length of SICU stay and postoperative hospital stay (Table 4).

\section{Discussion}

In this study, we prospectively analyzed the association of administration of exogenous albumin early after noncardiac surgery and postoperative AKI in patients with preoperative hypoalbuminemia. Although the patients of albumin group exhibited relatively higher serum albumin level on postoperative day 1, no difference was observed in postoperative AKI occurrence in patients of the two groups, and administration of albumin early after surgery did not improve other prognostic factors.

Cumulative evidence has shown that a perioperatively reduced serum albumin level may contribute to an increased risk of postoperative AKI in various clinical settings[1-4, 6, 7]. There are several factors responsible for the changes in albumin concentration after surgery: (1) Large amounts of fluid infusion during the operation leads to the dilution of plasma albumin; (2) The ability of liver to synthesize albumin decreases under stress; (3) Decomposition of albumin is increased to compensate for energy expenditure under stress; (4) The permeability of capillaries increases in the systemic inflammatory responses, and plasma albumin molecules leak out from the blood vessels; (5) Albumin is lost with blood loss during surgery. Among the above factors, the blood dilution and the exudation of albumin molecules out of the capillaries were considered to be the main causes of postoperative hypoalbuminemia[16, 17].

Currently, the conclusions of limited studies investigating the effect of perioperative exogenous albumin infusion on occurrence of postoperative AKI is not consistent. Eun-Ho Lee et al. prospectively reported that administration of exogenous albumin immediately before surgery reduced the risk of AKI after off-pump coronary artery bypass surgery in patients with a preoperative serum albumin level of less than $4.0 \mathrm{~g} / \mathrm{dl}$, although the observed difference in that study was only marginally significant $(P=0.048)$ [12]. On the contrary, in the retrospective cohort study of Anne Julie Frenette et al, a dose-dependent AKI risk associated with the administration of albumin until 36 hours after surgery was observed in patients undergoing on-pump cardiac surgery[18]. 
To the best of our knowledge, this is the first prospective cohort study investigating the association of albumin infusion early after non-cardiac surgery and incidence of postoperative AKI. In our study, there was no difference in occurrence of postoperative AKI in patients of the two groups, which indicated that administration of exogenous albumin early after surgery did not improve renal outcome. Several reasons were supposed to be responsible for the unbeneficial result. As mentioned above, surgery and the systemic inflammatory responses increase capillary permeability significantly, and massive albumin molecules leak out of the capillaries into the interstitial space, so the effect of correcting the hypoalbuminemia and the renal protective properties of serum albumin would not sustained. From this perspective, administration of exogenous albumin early after surgery, especially for major abdominopelvic surgery, is cost and unhelpful. On the contrary, with the subsidence of systemic inflammatory responses and the optimization of nutritional status, the level of serum albumin tends to recover spontaneously[19]. Additionally, in our study, although exogenous albumin was administrated early after surgery, the level of serum albumin in more than $89 \%$ patients was still lower than the threshold value, and the possibility that the dosage of exogenous albumin might not be sufficient could not be excluded completely. Furthermore, the causes of postoperative AKI are complicated and multifactorial. The isolated procedure of postoperative administration of exogenous albumin may not be enough to inhibit the pathological process leading to AKI in these high-risk patients.

There are several shortcomings in this study. Firstly, the standard of timing and dosage of albumin administration was absent. A definite treatment regime of albumin administration should be established. Secondly, a specific control fluid was not administrated in the patients of control group, although the difference in the positive fluid balance between the two groups was not significant. Finally, the sample size after propensity score matching was relatively small, and an expanded population would guarantee an increased statistical power. Therefore, a large randomized controlled study is needed to evaluate the above issues.

\section{Conclusions}

We concluded that the administration of exogenous albumin early after non-cardiac surgery had no benefit on the occurrence of postoperative AKI in patients with a preoperative serum albumin level of less than $37.5 \mathrm{~g} / \mathrm{L}$, and the procedure did not improve other prognostic outcomes. These findings need to be confirmed by further larger and randomized controlled clinical studies.

\section{Abbreviations}

AKI: acute kidney injury; SICU: Surgical Intensive Care Unit; CKD: chronic kidney disease; BMI: body mass index; ASA: American Society of Anesthesiology; SOFA: Sequential Organ Function Assessment; KDIGO: Kidney Disease Improving Global Outcomes; MV: mechanical ventilation; SD: standard deviation; ASD: absolute standard difference.

\section{Declarations}

\section{Ethics approval and consent to participate}

Ethical approval (2019-075) was provided by the Clinical Research Ethics Committee of Peking University First Hospital. We confirmed that all methods were performed in accordance with relevant guidelines and regulations. Written informed consents were obtained from patients, their next of kin or their legal representatives.

\section{Consent for publication}

Not applicable. 
Availability of data and materials

The datasets are not publicly available, but available from the corresponding author on reasonable request.

\section{Competing interests}

The authors declare that they have no competing interests.

\section{Funding}

The study was funded by the Clinical Research Program of Peking University First Hospital (2019CR09).

\section{Authors' Contributions}

MY helped design the study, analyze the data, and draft the manuscript. WJZ helped design the study and perform data collection. MX helped design the study and perform data collection. SNZ helped analyze and interpret data. NL helped design the study, perform data collection, analyze data, draft and revise the manuscript. SLL helped design the study and interpret data. All authors have read and approved the manuscript.

\section{Acknowledgements}

The authors gratefully acknowledge Professor Dong-Xin Wang for his suggestions on study design and data analysis.

\section{References}

1. Long T, Helgason D, Helgadottir S, Palsson R, Gudbjartsson T, Sigurdsson G, Indridason O, Sigurdsson M: Acute Kidney Injury After Abdominal Surgery: Incidence, Risk Factors, and Outcome. Anesthesia and analgesia 2016, 122(6):1912-1920.

2. Li N, Qiao H, Guo JF, Yang HY, Li XY, Li SL, Wang DX, Yang L: Preoperative hypoalbuminemia was associated with acute kidney injury in high-risk patients following non-cardiac surgery: a retrospective cohort study. BMC Anesthesiol 2019, 19(1):171.

3. Lee JH, Jung JY, Park SW, Song IK, Kim EH, Kim HS, Kim JT: Risk factors of acute kidney injury in children after cardiac surgery. Acta Anaesthesiol Scand 2018, 62(10):1374-1382.

4. Shin $\mathrm{KH}$, Han SB: Early postoperative hypoalbuminemia is a risk factor for postoperative acute kidney injury following hip fracture surgery. Injury 2018, 49(8):1572-1576.

5. Wei L, Nan L, Shuangling L: Relationship between postoperative immediate serum albumin level and postoperative acute kidney injury after major abdominal surgery in critically ill patients. Chin Crit Care Med 2021, 33(8):955-961.

6. Kim K, Bang JY, Kim SO, Kim S, Kim JU, Song JG: Association of preoperative hypoalbuminemia with postoperative acute kidney injury in patients undergoing brain tumor surgery: a retrospective study. J Neurosurg 2018, 128(4):1115-1122.

7. Li W, Li N, Li S: Relationship between postoperative immediate serum albumin level and postoperative acute kidney injury after major abdominal surgery in critically ill patients. Zhonghua wei zhong bing ji jiu yi xue 2021, 
33(8):955-961.

8. Iglesias J, Abernethy V, Wang Z, Lieberthal W, Koh J, Levine J: Albumin is a major serum survival factor for renal tubular cells and macrophages through scavenging of ROS. The American journal of physiology 1999, 277(5):F711722.

9. Wiedermann C, Joannidis M: Nephroprotective Potential of Human Albumin Infusion: A Narrative Review. Gastroenterology research and practice 2015, 2015:912839.

10. Horstick G, Lauterbach M, Kempf T, Bhakdi S, Heimann A, Horstick M, Meyer J, Kempski O: Early albumin infusion improves global and local hemodynamics and reduces inflammatory response in hemorrhagic shock. Critical care medicine 2002, 30(4):851-855.

11. Ha C, Bhagavan N: Novel insights into the pleiotropic effects of human serum albumin in health and disease. Biochimica et biophysica acta 2013, 1830(12):5486-5493.

12. Lee EH, Kim WJ, Kim JY, Chin JH, Choi DK, Sim JY, Choo SJ, Chung CH, Lee JW, Choi IC: Effect of Exogenous Albumin on the Incidence of Postoperative Acute Kidney Injury in Patients Undergoing Off-pump Coronary Artery Bypass Surgery with a Preoperative Albumin Level of Less Than 4.0 g/dl. Anesthesiology 2016, 124(5):1001-1011.

13. Ostermann M, Bellomo R, Burdmann E, Doi K, Endre Z, Goldstein S, Kane-Gill S, Liu K, Prowle J, Shaw A et al: Controversies in acute kidney injury: conclusions from a Kidney Disease: Improving Global Outcomes (KDIGO) Conference. Kidney international 2020, 98(2):294-309.

14. Ichai C, Vinsonneau C, Souweine B, Armando F, Canet E, Clec'h C, Constantin J, Darmon M, Duranteau J, Gaillot $T$ et al: Acute kidney injury in the perioperative period and in intensive care units (excluding renal replacement therapies). Anaesthesia, critical care \& pain medicine 2016, 35(2):151-165.

15. Austin P: Balance diagnostics for comparing the distribution of baseline covariates between treatment groups in propensity-score matched samples. Statistics in medicine 2009, 28(25):3083-3107.

16. Boldt J, Suttner S: Plasma substitutes. Minerva anestesiologica 2005, 71(12):741-758.

17. Renkin E, Tucker V, Rew K, O'Loughlin D, Wong M, Sibley L: Plasma volume expansion with colloids increases blood-tissue albumin transport. The American journal of physiology 1992, 262:H1054-1067.

18. Anne Julie Frenette, Josée Bouchard, Pascaline Bernier, Annie Charbonneau, Long Thanh Nguyen, Jean-Philippe Rioux, Stéphan Troyanov, Williamson DR: Albumin administration is associated with acute kidney injury in cardiac surgery a propensity score analysis. Critical Care 2014, 18:602.

19. Cai S, Luo N, Yuan X, He Y, Wu H, Wang Z: Is albumin administration beneficial in early stage of postoperative hypoalbuminemia after gastrointestinal surgery: a prospective randomized control trial. Chinese journal of surgery 2009, 47(10):744-747.

\section{Tables}

Table 1. Baseline and Preoperative Variables Used for Propensity Score Matching 


\begin{tabular}{|c|c|c|c|c|c|c|c|}
\hline & & Full cohort $(n$ & & & Matching c & rt $(n=128)$ & \\
\hline & $\begin{array}{l}\text { All } \\
(n=247)\end{array}$ & $\begin{array}{l}\text { Albumin } \\
\text { group } \\
(n=130)\end{array}$ & $\begin{array}{l}\text { Control } \\
\text { group } \\
(\mathrm{n}=117)\end{array}$ & ASD & $\begin{array}{l}\text { albumin } \\
\text { group } \\
(\mathrm{n}=64)\end{array}$ & $\begin{array}{l}\text { Control } \\
\text { group } \\
(n=64)\end{array}$ & ASD \\
\hline Age (y) & $\begin{array}{l}77(23- \\
99)\end{array}$ & $74(27-99)$ & $78(23-95)$ & 0.106 & 74 (29-97) & $78(23-95)$ & 0.004 \\
\hline Male sex & $\begin{array}{l}144 \\
(58.3 \%)\end{array}$ & 73 (56.2\%) & $71(60.7 \%)$ & 0.100 & $41(64.1 \%)$ & 38 (59.4\%) & 0.103 \\
\hline BMI $\left(\mathrm{kg} / \mathrm{m}^{2}\right)$ & $\begin{array}{l}23.0 \\
(14.3- \\
38.5)\end{array}$ & $\begin{array}{l}22.9(14.3- \\
37.0)\end{array}$ & $\begin{array}{l}23.3(16.6- \\
38.5)\end{array}$ & 0.183 & $\begin{array}{l}22.7(15.2- \\
31.8 \mathbb{}\end{array}$ & $\begin{array}{l}23.1(17.0- \\
36.2)\end{array}$ & 0.171 \\
\hline Hypertension & $\begin{array}{l}141 \\
(57.1 \%)\end{array}$ & 70 (53.8\%) & $71(60.7 \%)$ & 0.140 & 33 (51.6\%) & $36(56.3 \%)$ & 0.079 \\
\hline T2DM & $\begin{array}{l}65 \\
(26.3 \%)\end{array}$ & 35 (26.9\%) & $30(25.6 \%)$ & 0.022 & $18(28.1 \%)$ & $15(23.4 \%)$ & 0.110 \\
\hline CKD & $\begin{array}{l}34 \\
(13.8 \%)\end{array}$ & $17(13.1 \%)$ & $17(14.5 \%)$ & 0.059 & $9(14.1 \%)$ & $11(17.2 \%)$ & 0.086 \\
\hline $\begin{array}{l}\text { Preoperative } \\
\text { Albumin }(\mathrm{g} / \mathrm{L})\end{array}$ & $\begin{array}{l}33.9 \\
(20.7- \\
37.4)\end{array}$ & $\begin{array}{l}33.3(20.7- \\
37.4)\end{array}$ & $\begin{array}{l}34.6(21.0- \\
37.4)\end{array}$ & 0.367 & $\begin{array}{l}33.8(25.1- \\
37.4)\end{array}$ & $\begin{array}{l}33.6(21.0- \\
37.4)\end{array}$ & 0.071 \\
\hline $\begin{array}{l}\text { ASA } \\
\text { classification }\end{array}$ & & & & 0.029 & & & 0.000 \\
\hline I-II & $\begin{array}{l}35 \\
(14.2 \%)\end{array}$ & $18(13.8 \%)$ & $17(14.5 \%)$ & & $10(15.6 \%)$ & $10(15.6 \%)$ & \\
\hline III-IV & $\begin{array}{l}212 \\
(85.8 \%)\end{array}$ & $112(86.2 \%)$ & 100 (85.5\%) & & $54(84.4 \%)$ & $54(84.4 \%)$ & \\
\hline
\end{tabular}

Data are presented as mean $\pm \mathrm{SD}$, median (minimum-maximum) or number (percent).

Abbreviations: ASD, absolute standardized difference; BMI, body mass index; T2DM, Type 2 diabetes; CKD, chronic kidney disease; ASA, American Society of Anesthesiologists.

Table 2. Intraoperative and Postoperative Variables Used for Propensity Score Matching 


\begin{tabular}{|c|c|c|c|c|c|c|c|}
\hline & & Full cohort $(n=$ & 47) & & Matching c & ort $(n=128)$ & \\
\hline & $\begin{array}{l}\text { All } \\
(\mathrm{n}=247)\end{array}$ & $\begin{array}{l}\text { Albumin } \\
\text { group } \\
(n=130)\end{array}$ & $\begin{array}{l}\text { Control } \\
\text { group } \\
(n=117)\end{array}$ & ASD & $\begin{array}{l}\text { albumin } \\
\text { group } \\
(n=64)\end{array}$ & $\begin{array}{l}\text { Control } \\
\text { group } \\
(n=64)\end{array}$ & ASD \\
\hline Site of surgery & & & & 0.546 & & & 0.157 \\
\hline Abdominopelvic & $\begin{array}{l}157 \\
(63.6 \%)\end{array}$ & 96 (73.9\%) & $61(52.1 \%)$ & & 43 (67.2\%) & 37 (57.8\%) & \\
\hline Thoracic & $\begin{array}{l}26 \\
(10.5 \%)\end{array}$ & $12(9.2 \%)$ & $14(12.0 \%)$ & & $7(10.9 \%)$ & $9(14.1 \%)$ & \\
\hline Neural & $7(2.8 \%)$ & $2(1.5 \%)$ & $5(4.3 \%)$ & & $1(1.6 \%)$ & $3(4.7 \%)$ & \\
\hline Orthopedic & $\begin{array}{l}54 \\
(21.9 \%)\end{array}$ & 20 (15.4\%) & $34(29.0 \%)$ & & $13(20.3 \%)$ & 15 (23.4\%) & \\
\hline other & $3(1.2 \%)$ & $0(0.0 \%)$ & $3(2.6 \%)$ & & $0(0.0 \%)$ & $0(0.0 \%)$ & \\
\hline Type of surgery & & & & 0.158 & & & 0.137 \\
\hline Open & $\begin{array}{l}113 \\
(45.7 \%)\end{array}$ & $75(57.7 \%)$ & $38(32.5 \%)$ & & 35 (54.7\%) & 25 (39.1\%) & \\
\hline Laparoscopic & $\begin{array}{l}81 \\
(32.8 \%)\end{array}$ & $38(29.2 \%)$ & $43(36.7 \%)$ & & $20(31.3 \%)$ & $22(34.4 \%)$ & \\
\hline Non-relevant & $\begin{array}{l}53 \\
(21.5 \%)\end{array}$ & $17(13.1 \%)$ & $36(30.8 \%)$ & & $9(14.1 \%)$ & $17(26.6 \%)$ & \\
\hline $\begin{array}{l}\text { Duration of surgery } \\
(\mathrm{min} \rrbracket\end{array}$ & $\begin{array}{l}195(29- \\
925)\end{array}$ & $210(29-925)$ & $183(33-783)$ & 0.292 & $\begin{array}{l}186(29- \\
715)\end{array}$ & $\begin{array}{l}183(33- \\
783)\end{array}$ & 0.056 \\
\hline Type of anesthesia & & & & 0.530 & & & 0.141 \\
\hline General & $\begin{array}{l}234 \\
(94.7 \%)\end{array}$ & 127 (97.7\%) & 107 (91.5\%) & & 61 (95.3\%) & $60(93.8 \%)$ & \\
\hline Epidural & $\begin{array}{l}11 \\
(4.5 \%)\end{array}$ & $3(2.3 \%)$ & $8(6.8 \%)$ & & $3(4.7 \%)$ & $3(4.7 \%)$ & \\
\hline Reginal block & $2(0.8 \%)$ & $0(0.0 \%)$ & $2(1.7 \%)$ & & $0(0.0 \%)$ & $1(1.6 \%)$ & \\
\hline $\begin{array}{l}\text { Duration of } \\
\text { anesthesia (min) }\end{array}$ & $\begin{array}{l}279(70- \\
1012)\end{array}$ & $\begin{array}{l}289(84- \\
1012)\end{array}$ & $273(70-859)$ & 0.273 & $\begin{array}{l}255(84- \\
802)\end{array}$ & $\begin{array}{l}275(70- \\
859)\end{array}$ & 0.065 \\
\hline $\begin{array}{l}\text { Intraoperative } \\
\text { hypotension a }^{{ }^{2}}\end{array}$ & $\begin{array}{l}138 \\
(55.9 \%)\end{array}$ & 87 (66.9\%) & $51(43.6 \%)$ & 0.487 & $35(54.7 \%)$ & 38 (59.4\%) & 0.080 \\
\hline $\begin{array}{l}\text { Intraoperative } \\
\text { vasoactive drugs }\end{array}$ & $\begin{array}{l}151 \\
(61.1 \%)\end{array}$ & 88 (67.7\%) & 63 (53.8\%) & 0.299 & 41 (64.1\%) & $39(60.9 \%)$ & 0.062 \\
\hline $\begin{array}{l}\text { Intraoperative } \\
\text { hypotension (min) }\end{array}$ & $\begin{array}{l}15(5- \\
345)\end{array}$ & $20(5-345)$ & $10(5-240)$ & 0.177 & $15(5-120)$ & $10(5-240)$ & 0.024 \\
\hline $\begin{array}{l}\text { Postoperative } \\
\text { albumin }(\mathrm{g} / \mathrm{L})\end{array}$ & $\begin{array}{l}29.2 \\
(10.5- \\
41.9)\end{array}$ & $\begin{array}{l}27.2(10.5- \\
37.6)\end{array}$ & $\begin{array}{l}31.4(18.0- \\
41.9)\end{array}$ & 0.847 & $\begin{array}{l}29.3(19.8- \\
37.6)\end{array}$ & $\begin{array}{l}30.2(18.0- \\
38.9)\end{array}$ & 0.028 \\
\hline Non-renal SOFA & $\begin{array}{l}3.0(0.0- \\
11.0)\end{array}$ & $3.5(0.0-11.0)$ & $\begin{array}{l}3.0(0.0- \\
10.0)\end{array}$ & 0.523 & $\begin{array}{l}3.0(0.0- \\
10.0)\end{array}$ & $\begin{array}{l}3.0(0.0- \\
10.0)\end{array}$ & 0.177 \\
\hline
\end{tabular}


Data are presented as mean $\pm \mathrm{SD}$, median (minimum-maximum) or number (percent).

Abbreviations: ASD, absolute standardized difference; SOFA, sequential organ function assessment.

a Indicates intraoperative systolic blood pressure lower than $90 \mathrm{mmHg}$, or lower than the baseline value by more than $30 \%$.

${ }^{\mathrm{b}}$ Including dopamine, dobutamine, norepinephrine, ephedrine, phenylephrine, epinephrine and meta-hydroxylamine.

Table 3. Perioperative Variables Not Used for Propensity Score Matching

\begin{tabular}{|c|c|c|c|c|c|c|c|}
\hline & \multirow[b]{2}{*}{ All $(n=247)$} & \multicolumn{3}{|c|}{ Full cohort $(n=247)$} & \multicolumn{3}{|c|}{ Matching cohort $(n=128)$} \\
\hline & & $\begin{array}{l}\text { Albumin } \\
\text { group } \\
(n=130)\end{array}$ & $\begin{array}{l}\text { Control } \\
\text { group } \\
(n=117)\end{array}$ & $P$ value & $\begin{array}{l}\text { Albumin } \\
\text { group } \\
(n=64)\end{array}$ & $\begin{array}{l}\text { Control } \\
\text { group } \\
(n=64)\end{array}$ & $P$ value \\
\hline \multicolumn{8}{|l|}{$\begin{array}{l}\text { Preoperative } \\
\text { comorbidities }\end{array}$} \\
\hline $\begin{array}{l}\text { Coronary heart } \\
\text { disease }\end{array}$ & 79 (32.0\%) & 33 (25.4\%) & $46(39.3 \%)$ & 0.019 & 20 (31.3\%) & 19 (29.7\%) & 0.848 \\
\hline $\begin{array}{l}\text { Cerebrovascular } \\
\text { disease }\end{array}$ & 44 (17.8\%) & $26(20.0 \%)$ & $18(15.4 \%)$ & 0.344 & $10(15.6 \%)$ & $12(18.8 \%)$ & 0.639 \\
\hline $\begin{array}{l}\text { Preoperative } \mathrm{Hb} \\
(\mathrm{g} / \mathrm{L})\end{array}$ & $108.5 \pm 18.5$ & $108.1 \pm 17.8$ & $109.0 \pm 19.2$ & 0.723 & $108.4 \pm 16.3$ & $105.0 \pm 19.0$ & 0.834 \\
\hline $\begin{array}{l}\text { Baseline serum } \\
\text { creatinine } \\
(\mu \mathrm{mol} / \mathrm{L})\end{array}$ & $\begin{array}{l}72.6(18.1- \\
286.8)\end{array}$ & $\begin{array}{l}71.1(27.9- \\
286.8)\end{array}$ & $\begin{array}{l}74.6(18.1- \\
238.31)\end{array}$ & 0.151 & $\begin{array}{l}75.6(44.7- \\
242.0)\end{array}$ & $\begin{array}{l}68.11 \\
(18.1- \\
238.3)\end{array}$ & 0.464 \\
\hline $\begin{array}{l}\text { Baseline eGFR } \\
{\left[\mathrm{ml} /\left(\min \cdot 1.73 \mathrm{~m}^{2}\right)\right]}\end{array}$ & $\begin{array}{l}82.2(18.8- \\
156.1)\end{array}$ & $\begin{array}{l}81.5(22.4- \\
156.1)\end{array}$ & $\begin{array}{l}82.9(18.8- \\
134.5)\end{array}$ & 0.198 & $\begin{array}{l}81.4(22.6- \\
132.4)\end{array}$ & $\begin{array}{l}83.5(25.0- \\
156.1)\end{array}$ & 0.637 \\
\hline $\begin{array}{l}\text { Preoperative BNP } \\
(\mathrm{pg} / \mathrm{ml})\end{array}$ & $\begin{array}{l}92.0(2.8- \\
1622.0)\end{array}$ & $\begin{array}{l}86.5(2.8- \\
1197.0)\end{array}$ & $\begin{array}{l}99.0(9.0- \\
1622.0)\end{array}$ & 0.623 & $\begin{array}{l}80.0(9.0- \\
1197.0)\end{array}$ & $\begin{array}{l}81.0(9.0- \\
791.0)\end{array}$ & 0.792 \\
\hline $\begin{array}{l}\text { Radiocontrast } \\
\text { exposure }\end{array}$ & 25 (10.1\%) & 15 (11.5\%) & $10(8.5 \%)$ & 0.436 & $7(10.9 \%)$ & $6(9.4 \%)$ & 0.770 \\
\hline On ACEI/ARB & $41(16.6 \%)$ & $14(10.8 \%)$ & 27 (23.1\%) & 0.009 & $6(9.4 \%)$ & $10(15.6 \%)$ & 0.285 \\
\hline $\begin{array}{l}\text { Emergency } \\
\text { surgery }\end{array}$ & 22 (8.9\%) & 18 (13.8\%) & $4(3.4 \%)$ & 0.004 & $6(9.4 \%)$ & $4(6.3 \%)$ & 0.510 \\
\hline $\begin{array}{l}\text { Intraoperative } \\
\text { estimated } \\
\text { blood loss (ml) }\end{array}$ & $\begin{array}{l}100(5- \\
6000)\end{array}$ & $\begin{array}{l}100(5- \\
6000)\end{array}$ & $\begin{array}{l}100(5- \\
2000)\end{array}$ & 0.089 & $\begin{array}{l}100(10- \\
1700)\end{array}$ & $\begin{array}{l}100(5- \\
2000)\end{array}$ & 0.669 \\
\hline
\end{tabular}

Data are presented as mean $\pm \mathrm{SD}$, median (minimum-maximum) or number (percent).

Abbreviations: Hb, hemoglobin; eGFR, estimated glomerular filtration rate; BNP, type B natriuretic peptide; ACEI/ARB, angiotensin-converting enzyme inhibitor/angiotensin receptor blocker.

Table 4. Primary and Secondary Outcomes of the Study in Matched Patients 


\begin{tabular}{|c|c|c|c|c|}
\hline & $\begin{array}{l}\text { Total } \\
(\mathrm{n}=128)\end{array}$ & $\begin{array}{l}\text { albumin group } \\
(\mathrm{n}=64)\end{array}$ & $\begin{array}{l}\text { Control group } \\
(\mathrm{n}=64)\end{array}$ & $\begin{array}{l}P \\
\text { value }\end{array}$ \\
\hline Postoperative AKI & 78 (60.9\%) & 38 (59.4\%) & 40 (62.5\%) & 0.717 \\
\hline Albumin on postoperative day $1(\mathrm{~g} / \mathrm{L})$ & $30.6 \pm 3.6$ & $31.3 \pm 3.4$ & $29.7 \pm 3.8$ & 0.008 \\
\hline $\begin{array}{l}\text { Positive fluid balance on the day of SICU } \\
\text { admission }(\mathrm{ml} / \mathrm{kg})\end{array}$ & $\begin{array}{l}34.0(4.0- \\
337.0)\end{array}$ & $36.5(4.0-337.0)$ & $32.0(4.0-128.0)$ & 0.064 \\
\hline On MV in SICU & $62(48.4 \%)$ & $30(46.9 \%)$ & $32(50.0 \%)$ & 0.724 \\
\hline Duration of MV (h) & $6(1-1128)$ & $6(2-392)$ & $6.5(1-1128)$ & 0.745 \\
\hline $\begin{array}{l}\text { Number of postoperative complications except } \\
\text { AKI }\end{array}$ & $0(0-12)$ & $0(0-11)$ & $0(0-12)$ & 0.116 \\
\hline In-hospital mortality & $6(4.7 \%)$ & $2(3.1 \%)$ & $4(6.3 \%)$ & 0.676 \\
\hline Length of SICU stay (d) & $\begin{array}{l}1.5(1.0- \\
66.0)\end{array}$ & $2.0(1.0-23.0)$ & $1.0(1.0-66.0)$ & 0.090 \\
\hline Postoperative hospital stay (d) & $11(2-72)$ & $11(2-72)$ & $11.5(2-71)$ & 0.778 \\
\hline
\end{tabular}

Data were presented as mean $\pm S D$, median (minimum-maximum) or number (percentage).

Abbreviations: AKI, acute kidney injury; SICU, Surgical Intensive Care Unit; MV, mechanical ventilation.

\section{Figures}




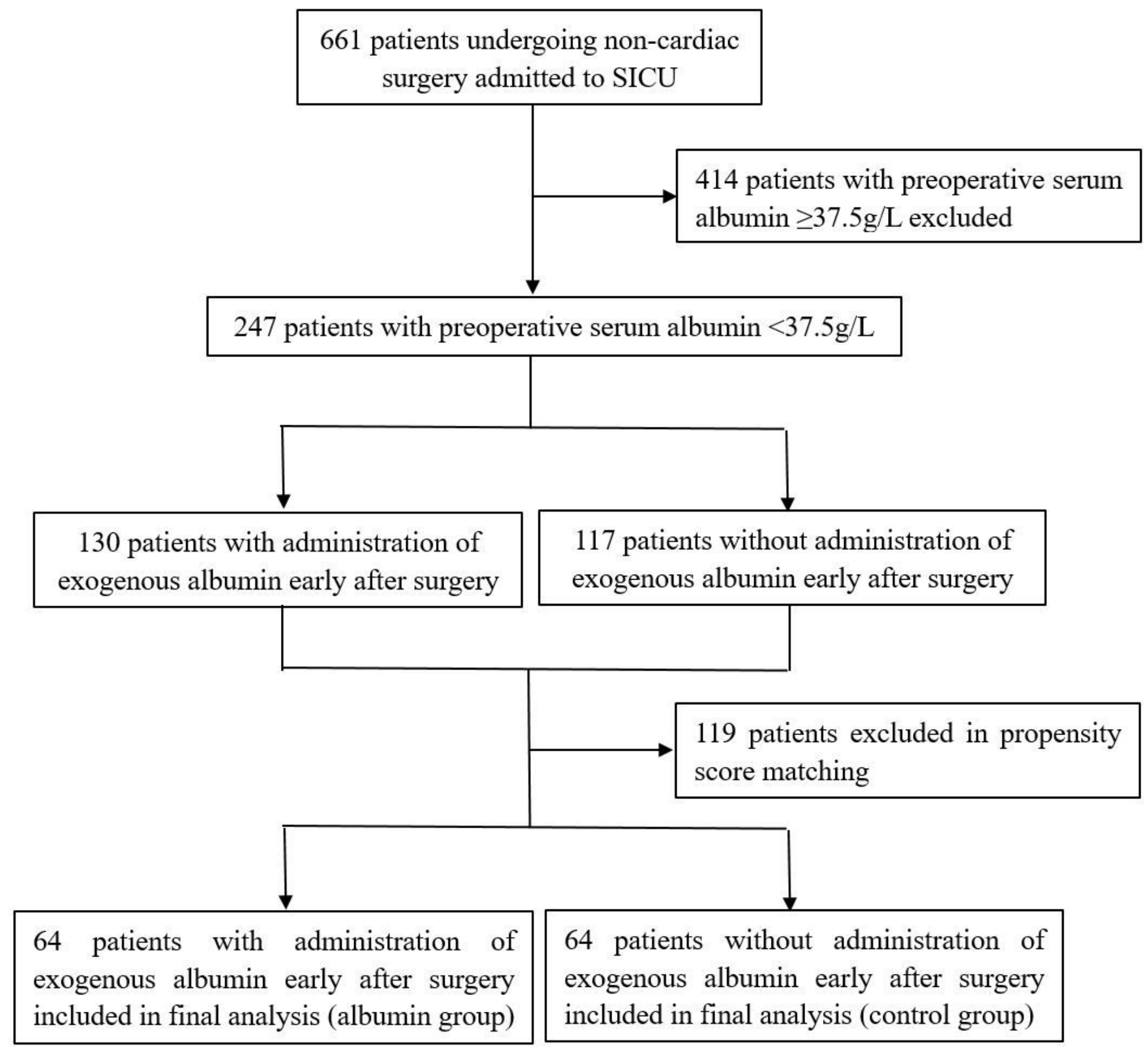

Figure 1

Flowchart of the study.

\section{Supplementary Files}

This is a list of supplementary files associated with this preprint. Click to download.

- Tables1.docx 